\title{
HIV and NCDs: inevitable interaction in resource limited settings.
}

\author{
James K Tumwine
}

DOI: https://dx.doi.org/10.4314/ahs.v17i4.1

Cite as: Tumwine JK. HIV and NCDs: inevitable interaction in resource limited settings. Afri Health Sci. 2017;17(4): i-iv. https:/ / dx.doi. org/10.4314/abs.v17i4.1

As the incidence of infectious diseases in LMICs takes a back seat, thanks to the effective vaccines and other public health measures, the importance of non-communicable diseases (NCDs) has come to the fore. ${ }^{1}$ It is in line with this that we highlight HIV and NCDs in Africa as the main theme of this December 2017 issue of AHS.

\section{HIV / AIDS and other infections}

Nalukwago and others from $\mathrm{Uganda}^{2}$ are the authors of our lead article in this issue. They sought to establish the effect of interrupted ART on reconstitution of CD4 and CD8 subsets in TB patients. They found that there was a significant increase of naive $\mathrm{CD}^{+}$cells and a decrease in effector $\mathrm{CD}^{+}$cells to values near the baseline. They concluded that interrupting ART alters $\mathrm{CD} 8^{+}$, but not $\mathrm{CD}^{+}$ subsets in patients with less advanced HIV infection and TB.

Namara-Lugolobi and others, also from Uganda, studied factors associated with unknown HIV status among women delivering in Uganda's national and teaching hospital in Kampala. ${ }^{3}$ They found that only 3\% of women in labour had an unknown HIV result. Attending ANC and being counselled for HIV testing were associated with having a known HIV status.

Still with the infectious disease theme, we have work on $\mathrm{HIV} /$ hepatitis coinfection, ${ }^{4}$ client type and condom use for HIV, and prevention in Kenya. ${ }^{5}$

We have an interesting paper on angio-converting enzyme insertion/deletion polymorphism and susceptibility to Kawasaki disease, ${ }^{6}$ and the mec $A$ gene among staphylococci from clinical samples in Nigeria. ${ }^{7}$ Still in line with the microbiology interest, Chinese authors have written for us a beautiful article on evaluation and improvement of LAMP assays for analysis of Escherichia coli serogroups. They assert that LAMP assays are highly susceptible to non-specific amplication by primer divers. ${ }^{8}$
Does anyone worry about hepatitis E? Well, you should! One in every 8 pig abattoir worker in Kampala tested positive for hepatitis $E$. This in a country with a hepatitis E pandemic in the Karamoja region. ${ }^{9}$

We end this infectious disease treatise with an interesting study on trypanosomiasis in Kenya. Maina found that rats infected with Trypanosoma brucei brucei had abnormal ACTH concentration and histological changes in the pituitary gland. ${ }^{10}$

Now to non-communicable diseases (NCDs)

Cancer:

Chinese scientists report on cases of breast cancer patients with metastases to the thyroid ${ }^{11}$ while Nwadike and others have written on mammographic classification of breast lesions among women in Nigeria. ${ }^{12}$ The cancer treatise ends with a study of gastrointestinal malignancies in 5 regional referral hospitals in Uganda. ${ }^{13}$ They found that oesophageal, liver, stomach and colorectal cancers are common with increasing trends.

Obesity is a serious NCD. Saudi scientists studied genetic polymorphism of FTO, and found an association between FTO genotype with increasing weight, BMI and leptin. ${ }^{14}$ On the other hand, Nigeria and US scientists studied the CVD risk factors in adult outpatients in rural urban health facilities in Nigeria. They found CVD risk factors highly prevalent. Many were not yet diagnosed and unaware. ${ }^{15}$

A unique study from Mauritius sheds light on oral dysbacteriosis in type 2 diabetes and its role in the progression to cardiovascular disease ${ }^{16}$ while Nigerian authors report on QTC prolongation in black diabetic subjects with cardiac autonomic neuropathy. ${ }^{17}$

Now NCDs and the environment: An interesting study from India reports on outdoor aeroallergen and CD14 C(-159) $\mathrm{T}$ polymorphism in asthma severity in Kolkata, ${ }^{18}$ while 
Nigerian authors ${ }^{19}$ report on factors associated with tobacco smoking among long distance drivers in Lagos.

\section{Growth and development}

Abnormalities of the external genitalia and groin are common in Nigeria affecting over a third of boys in primary school. ${ }^{20}$ This report is followed by Odiit's letter on childhood kidney diseases in Uganda, ${ }^{21}$ and a South African report on childhood idiopathic nephrotic syndrome. ${ }^{22}$

It is tempered by a Tunisian study on the long term effect of a school based intervention to prevent chronic diseases. ${ }^{23}$ Then follows a case study of the reality of everyday communication for a deaf child, using sign language. ${ }^{24}$ The child health theme continues with a South African paper on astigmatism, ${ }^{25}$ followed by one highlighting suicidal ideation among adolescents in Swaziland. ${ }^{26}$ The section ends with intestinal candidiasis and antibiotics in Nsukka, Nigeria. ${ }^{27}$

Health system issues: The issue of universal health coverage is in vogue. In line with this, Zambian and South African authors assessed regional variations in the effect of removal of user charges on facility based deliveries in Zambia. ${ }^{28}$ Still in South Africa, Oosthuizen and others report on market dynamics of selective serotonin re-uptake inhibitors, in the private sector. ${ }^{29}$

We conclude this health systems section with a piece on the "Physician's Pledge", a sort of dot.com version of the famous Hippocratic oath taken by doctors on graduation. ${ }^{30}$ So relevant to ongoing discussions on the ethics of medical practice in a continent with endemic corruption and poorly funded public health services.

The rest of the papers are on erythrocyte ATPase activity, ${ }^{31}$ neurocalcin-delta, ${ }^{32}$ corneal macular retinal nerve fiber, ${ }^{33}$ and middle ear malfunction in the elderly. ${ }^{34}$ In addition, we have papers on bowel injury following gynaecological laparoscopic surgery, ${ }^{35}$ and erroneous opinion on cause of death. ${ }^{36}$

This has given us a glimpse into what the AHS team has prepared in this $4^{\text {th }}$ issue of AHS in 2017: NCDs and infections.

\section{References}

1. van Heerden A, Barnabas RV, Norris SA, Micklesfield LK, van Rooyen H, Celum C. High prevalence of HIV and non-communicable disease (NCD) risk factors in rural KwaZulu-Natal, South Africa. J Int AIDS Soc. 2017 Oct;20(2). doi: 10.1002/jia2.25012.

2. Nalukwago S, Lancioni CL, Oketcho JB, Canaday DH, Boom WH, Ojok L, Mayanja-Kizza H. The effect of interrupted anti-retroviral treatment on the reconstitution of memory and naive $\mathrm{T}$ cells during tuberculosis treatment in HIV patients with active pulmonary tuberculosis. Afri Health Sci.2017;17(4): 954-962. https://dx.doi. org/10.4314/ahs.v17i4.2

3. Namara-Lugolobi EC, Nakigozi G, Namukwaya Z, Kaye DK, Nakku-Joloba E. Prevalence and predictors of unknown HIV status among women delivering in Mulago National Referral Hospital, Kampala, Uganda. Afri Health Sci.2017;17(4): 963-973. https://dx.doi.org/10.4314/ahs. v17i4.3

4. Katwesigye E, Seremba E, Semitala F, Ocama P. Low sero-prevalence of hepatitis delta antibodies in HIV/ hepatitis B co-infected patients attending an urban HIV clinic in Uganda. Afri Health Sci.2017;17(4): 974-978. https://dx.doi.org/10.4314/ahs.v17i4.4

5. Broel E, Huber LB, Warren-Findlow J, Racine E. The association between client type and condom use with steady and unsteady partners among persons seeking HIV testing and counseling services in Kenya. Afri Health Sci.2017;17(4): 979-990. https://dx.doi.org/10.4314/ahs. v17i4.5

6. Pan Y, Lu H. Angiotensin-converting enzyme insertion/deletion polymorphism and susceptibility to Kawasaki disease: a meta-analysis. Afri Health Sci.2017;17(4): 991-999. https://dx.doi.org/10.4314/ahs.v17i4.6

7. Ibadin EE, Enabulele IO, Muinah F. Prevalence of mecA gene among staphylococci from clinical samples of a tertiary hospital in Benin City, Nigeria. Afri Health Sci.2017;17(4): 1000-1010. https://dx.doi.org/10.4314/ ahs.v17i4.7

8. Wang D. Evaluation and improvement of LAMP assays for detection of Escherichia coli serogroups O26, O45, O103, O111, O121, O145, and O157. Afri Health Sci.2017;17(4): 1011-1021. https://dx.doi.org/10.4314/ ahs.v17i4.8

9. Ukuli AQ, Mugimba KK. Seroprevalence of hepatitis E in swine abattoir workers. Afri Health Sci.2017;17(4): 1022-1028. https://dx.doi.org/10.4314/ahs.v17i4.9

10. Maina CI. Plasma ACTH concentration and pituitary gland histo-pathology in rats infected with Trypanosoma brucei brucei. Afri Health Sci.2017;17(4): 1029-1034. https://dx.doi.org/10.4314/ahs.v17i4.10 
11. Zhou L, Chen L, Xu D, Shao Q, Guo Z, Ge M. Breast cancer metastasis to thyroid: a retrospective analysis. Afri Health Sci.2017;17(4): 1035-1043. https://dx.doi. org/10.4314/ahs.v17i4.11

12. Nwadike UI, Eze CU, Agwuna K, Mouka C. Mammographic classification of breast lesions amongst women in Enugu, South East Nigeria. Afri Health Sci.2017;17(4): 1044-1050. https://dx.doi.org/10.4314/ahs.v17i4.12

13. Obayo S, Lukwago L, Orem J, Faulx AL, Probert CS. Gastrointestinal malignancies at five regional referral hospitals in Uganda. Afri Health Sci.2017;17(4): 1051-1058. https://dx.doi.org/10.4314/ahs.v17i4.13

14. Moselhy SS, Alhetari YA, Iyer A, Huwait EA, AL-Ghamdi MA , AL-Ghamdi S, Balamash KS, Basuni AA, Alama MN, Kumosani TA, Yaghmoor SS. Analysis of SNPs of MC4R, GNB3 and FTO gene polymorphism in obese Saudi subjects. Afri Health Sci.2017;17(4): 1059-1069. https://dx.doi.org/10.4314/ahs.v17i4.14

15. Onyemelukwe GC, Ogunfowokan O, Mbakwem A, Alao AK, Soroh K, Omorodion O, Abreu P. Cardiovascular risk factors in adult general out-patient clinics in $\mathrm{Ni}$ geria: a country analysis of the Africa and Middle East Cardiovascular Epidemiological (ACE) study. Afri Health Sci.2017;17(4): 1070-1081. https://dx.doi.org/10.4314/ ahs.v17i4.15

16. Nabee Z, Jeewon R, Pugo-Gunsam P. Oral dysbacteriosis in type 2 diabetes and its role in the progression to cardiovascular disease. Afri Health Sci.2017;17(4): 10821091. https://dx.doi.org/10.4314/ahs.v17i4.16

17. Ukpabi OJ, Onwubere BJC. QTc prolongation in Black diabetic subjects with cardiac autonomic neuropathy. Afri Health Sci.2017;17(4): 1092-1100. https://dx.doi. org/10.4314/ahs.v17i4.17

18. Dutta S, Mondal P, Saha NC, Moitra S, Podder S, Ghosh A, Saha GK. Role of offending out-door aero-allergen and CD14 C(-159)T polymorphism in development and severity of asthma in a Kolkata patient population. Afri Health Sci.2017;17(4):1101-1109. https:// dx.doi.org/10.4314/ahs.v17i4.18

19. Ozoh OB, Akanbi MO, Amadi CE, Vollmer WM, Bruce NG. The prevalence of and factors associated with tobacco smoking behavior among long-distance drivers in Lagos, Nigeria. Afri Health Sci.2017;17(4):1110-1119. https://dx.doi.org/10.4314/ahs.v17i4.19

20. Adekanye AO, Adefemi SA, Onawola KA, James JA, Adeleke IT, Francis M, Sheshi EU, Atakere ME, Jibril AD. Abnormalities of the external genitalia and groins among primary school boys in Bida, Nigeria. Afri Health Sci.2017;17(4):1120-1125.https://dx.doi.org/10.4314/ ahs.v17i4.20

21. Odiit A. Common childhood kidney diseases in Uganda and their prevention. Afri Health Sci.2017;17(4):11261129. https://dx.doi.org/10.4314/ahs.v17i4.21

22. Bakhiet YM, Mudi A, Khumalo T, Moonsamy G, Levy C. Idiopathic nephrotic syndrome in South African children. Afri Health Sci.2017;17(4):1130-1136. https:// dx.doi.org/10.4314/ahs.v17i4.22

23. Ghammam R, Maatoug J , Zammit N, Kebaili R, Boughammoura L, Al'Absi M, Lando H, Ghannem H. Long term effect of a school based intervention to prevent chronic diseases in Tunisia, 2009-2015. Afri Health Sci.2017;17(4):1137-1148.https://dx.doi.org/10.4314/ ahs.v17i4.23

24. Blose ZM, Joseph LN. The reality of every day communication for a deaf child using sign language in a developing country. Afri Health Sci.2017;17(4):1149-1159. https://dx.doi.org/10.4314/ahs.v17i4.24

25. Wajuihian SO. Characteristics of astigmatism in Black South African high school children. Afri Health Sci.2017;17(4):1160-1171.https://dx.doi.org/10.4314/ ahs.v17i4.25

26. Almansour AM, Siziya S. Suicidal ideation and associated factors among school going adolescents in Swaziland. Afri Health Sci.2017;17(4):1172-1177. https://dx. doi.org/10.4314/ahs.v17i4.26

27. Ezeonu IM, Ntun NW, Ugwu KO. Intestinal candidiasis and antibiotic usage in children: case study of Nsukka, South Eastern Nigeria. Afri Health Sci.2017;17(4):11781184. https://dx.doi.org/10.4314/ahs.v17i4.27

28. Chitalu C-C, Steven K. Assessing regional variations in the effect of the removal of user fees on facility-based deliveries in rural Zambia. Afri Health Sci.2017;17(4):11851196. https://dx.doi.org/10.4314/ahs.v17i4.28

29. Oosthuizen F, Kondiah PJ, Moosa HB, Naroth S, Patel NI, Reddy D, Soobramoney A. The market dynamics of selective serotonin re-uptake inhibitors: a private sector study in South Africa. Afri Health Sci.2017;17(4):11971202.https://dx.doi.org/10.4314/ahs.v17i4.29

30. Anonymous. World Medical Association Declaration of Geneva. Afri Health Sci.2017;17(4):1203. https://dx. doi.org/10.4314/ahs.v17i4.30

31. Kherd AA, Helmi N, Balamash KS , Kumosani TA, AL-Ghamdi SA, Qari M, Huwait EA, Yaghmoor SS, Nabil A, AL-Ghamdi MA, Moselhy SS. Changes in 
erythrocyte ATPase activity under different pathological conditions. Afri Health Sci.2017;17(4):1204-1210. https:// dx.doi.org/10.4314/ahs.v17i4.31

32. Ma W-W, Ding B-J, Yuan L-H, Zhao L, Yu H-L, Xi Y-d, Xiao R. Neurocalcin-delta: a potential memory-related factor in hippocampus of obese rats induced by highfat diet. Afri Health Sci.2017;17(4):1211-1221. https:// dx.doi.org/10.4314/ahs.v17i4.32

33. Mashige KP. Reproducibility of corneal, macular and retinal nerve fiber layer thickness measurements using the iVue-100 optical coherence tomography. Afri Health Sci.2017;17(4):1222-1228.https://dx.doi.org/10.4314/ ahs.v17i4.33
34. Sogebi OA, Adedeji TO, Ogunbanwo O, Oyewole EA. Sub-clinical middle ear malfunctions in elderly patients; prevalence, pattern and predictors. Afri Health Sci.2017;17(4):1229-1236.https://dx.doi.org/10.4314/ ahs.v17i4.34

35. Elbiss HM, Abu-Zidan FM. Bowel injury following gynecological laparoscopic surgery. Afri Health Sci.2017;17(4):1237-1245.https://dx.doi.org/10.4314/ ahs.v17i4.35

36. Banwari M. An erroneous opinion on a cause of death in a forensic autopsy: a case report. Afri Health Sci.2017;17(4):1246-1249.https://dx.doi.org/10.4314/ ahs.v17i4.36 